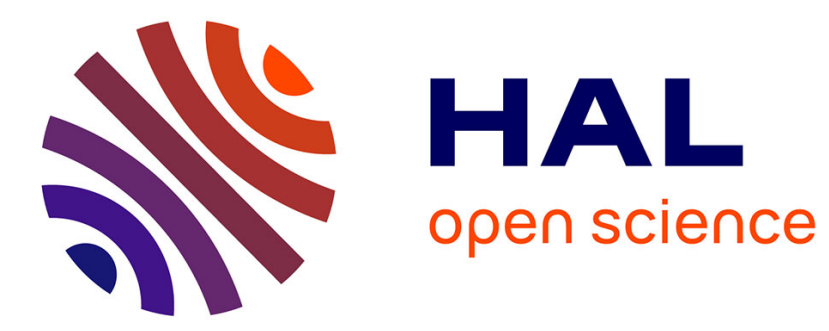

\title{
INVESTIGATION OF ELECTROMAGNETIC FIELDS AT A ROUGH Ag SURFACE BY DIFFERENTIAL REFLECTOMETRY OF Cu AND Al ADSORBATES
}

T. López-Ríos, Yves Borensztein, G. Vuye

\section{- To cite this version:}

T. López-Ríos, Yves Borensztein, G. Vuye. INVESTIGATION OF ELECTROMAGNETIC FIELDS AT A ROUGH Ag SURFACE BY DIFFERENTIAL REFLECTOMETRY OF $\mathrm{Cu}$ AND Al ADSORBATES. Journal de Physique Colloques, 1983, 44 (C10), pp.C10-353-C10-356. 10.1051/jphyscol:19831071 . jpa-00223529

HAL Id: jpa-00223529

https://hal.science/jpa-00223529

Submitted on 1 Jan 1983

HAL is a multi-disciplinary open access archive for the deposit and dissemination of scientific research documents, whether they are published or not. The documents may come from teaching and research institutions in France or abroad, or from public or private research centers.
L'archive ouverte pluridisciplinaire HAL, est destinée au dépôt et à la diffusion de documents scientifiques de niveau recherche, publiés ou non, émanant des établissements d'enseignement et de recherche français ou étrangers, des laboratoires publics ou privés. 


\title{
INVESTIGATION OF ELECTROMAGNETIC FIELDS AT A ROUGH Ag SURFACE BY DIFFERENTIAL REFLECTOMETRY OF CU AND AI ADSORBATES
}

\author{
T. López-Ríos, Y. Borensztein and G. Vuye \\ Laboratoire d'optique des Solides, Université Pierre et Marie Curie, 4, Place \\ Jussieu, 75230 Paris Cedex 05, France
}

\begin{abstract}
Résumé - Des dépôts inférieurs à la monocouche de Cu et d'Al, évaporés sur des surfaces rugueuses d'argent préparées par trempe sur des substrats refroidis à $120 \mathrm{~K}$, sont étudiês par réflectivitê diffërentielle dans la gamme spectrale 2-4 eV. Pour chacun des adsorbats ( $C$ et A1) des absorptions optiques similaires sont observées à environ $1.8 \mathrm{eV}$ et $3 \mathrm{eV}$, et sont attribuées sans ambiguité à la rugositê de surface. On trouve que 1'absorption optique à $\hat{~} 1.8 \mathrm{eV}$ a à peu près 1 a même position spectrale et la même largeur que le spectre d'excitation S.E.R.S. présenté par Pockrand (Chem. Phys. Lett. 92 (1982) 514) pour des surfaces d'Ag analogues aux nôtres.

Abstract - Submonolayer deposits of Copper and Aluminium on rough silver surfaces prepared by quenching silver on substrates cooled to $120 \mathrm{~K}$ are studied by differential reflectivity in the $2-4 \mathrm{eV}$ spectral region. For both adsorbates ( $\mathrm{Cu}$ and Al) similar optical absorptions are observed at

$\sim 1.8 \mathrm{eV}$ and $\sim 3 \mathrm{eV}$ and are unambiguously assigned to surface roughness. It is found that the optical absorption at $\imath 1.8 \mathrm{eV}$ has rearly the same spectral position and width than SERS excitation spectra reported by Pockrand (Chem. Phys. Lett. 92 (1982) 514) for Ag surfaces similar to ours
\end{abstract}

\section{INTRODUCTION}

A large number of theoretical investigations on surface enhanced Raman scattering (SERS) have been devoted to studying electromagnetic field amplification at a rough surface by several possible mechanisms like the needle effect or localized resonances at surface bumps, but the real importance of field enhancement and the subsequent amplification of Stokes radiation by " the antenna " effect is not yet well understood.

In this communication we report on differential reflectivity measurements of Cu and Al adsorbates on $\mathrm{Ag}$ surfaces with the aim of investigating electromagnetic fields at the surface. The optical absorption by an atom or a molecule adsorbed on a surface is proportional to $\operatorname{Im}(\varepsilon) . \mathrm{E}^{2}$ where $\varepsilon$ is the atom or molecule dielectric constant and $E$ the local field seen by the molecule/1/. If $E$ has a resonant behaviour as is expected, for instance, for surface plasmon excitation on bumps, optical absorption and differential reflectivity will indicate the intensity and spectral va riations of the local field $\mathrm{E}$. Reflectivity changes induced by an adsorbate are due to optical absorption modifications on the substrate produced by the adsorbate and to optical absorption of the adsorbate itself. For highly reflecting substrates (such as silver in the visible range) and absorbing molecules, the molecular absorption is the main contribution to the reflectivity changes.

A relationship was established in several SERS experiments / 2,3,4/ between SERS excitation spectra and optical absorption, but, as was underlined by weitz et a1 $/ 5 /$, optical absorption on bumps and the electromagnetic field at the surface are not necessarily maximum at the same energy. In this communication we present preliminary results for " cold Ag surfaces " prepared by condensing silver on substrates at $\approx 120 \mathrm{~K}$. 


\section{EXPER IMENTAL}

The experiments were carried out in a U H V system and differential reflectivity $\Delta R / R$ measurements at normal incidence were performed with an optical set-up based on a fast $(800 \mathrm{~Hz})$ optical scanning between a clean surface and an identical surface covered by the adsorbates under investigation. The samples are prepared by evaporating Ag on carefully polished silica substrates, with the pressure remaining lower than $10^{-9}$ torr during evaporation.

\section{RESULTS AND DISCUSSION}

Fig 1 shows differential reflectivity $\Delta R / R=2\left(R^{\prime}-R\right) /\left(R^{\prime}+R\right)$ measurements at normal incidence vshw becween a Ag film, 1660 \& thick, deposined at $150 \mathrm{~K}$ (R) and the same surface covered by $C u$ deposits of various thicknesses ( $R^{\prime}$ ). $\Delta R / R$ values when the thicker $\mathrm{Cu}$ deposit $(2.6 \AA)$ is exposed to $150 \mathrm{~L}$ of oxygen are also represented. Negative values of $\Delta R / R$ indicate a lower reflectivity (more absorption) for the covered surface. The prominent minima at $3.9 \mathrm{eV}$ (out of the drawing on the figure) is indicative of the very small values of reflectivity for silver at this frequency and is discussed in detail elsewhere / $6 /$. In fig. I there are two features located at $1.8 \mathrm{eV}$ and $3 \mathrm{eV}$. Fig 2 shows the same kind of experiments as in fig 1 but for Al deposits from $0.55 \AA$ to $3.3 \AA$. It presents features similar to those observed in fig l, at nearly the same frequencies. The fact that equivalent curves are obtained for two different adsorbates clearly indicates that the observed structures are not related to the adsorbate dielectric constant but to the rough surface itself. It is not possible to determine the origin of the observed features from the present experiments. Nevertheless, it must be pointed out that the shoulder at $\sim 3 \mathrm{eV}$, in experiments not reported here, continuously shifts with annealing to $3.5 \mathrm{eV}$ (the surface plasmon energy for a nearly flat surface), whereas the absorption band at about $1.8 \mathrm{eV}$ shifts, with increasing temperatures, to higher frequencies and finally completely desappears at room temperature. It is possible that
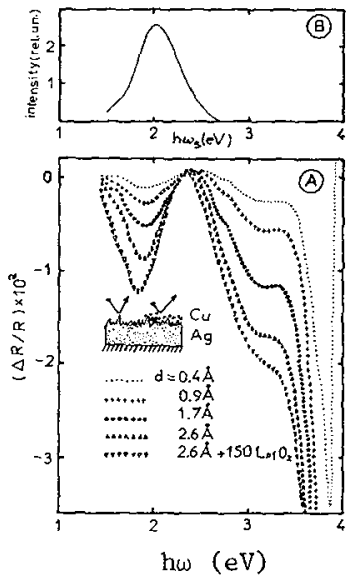

Fig. 1-a) Differential reflectivity $\Delta R / R$ vs photon energy hw for $\mathrm{Cu}$ overlayers of different thickness d on a $\mathrm{Ag}$ surface prepared by condensing $1660 \AA$ of silver on a substrate at $150 \mathrm{~K} . \Delta R / R$ is also indicated when the sample (with a $\mathrm{Cu}$ overlayer $2.6 \AA$ thick) is exposed to $150 \mathrm{~L}$ of $\mathrm{O}_{2}$.

b) Excitation spectrum as a function of the Stokes energy ( $\operatorname{ref} \overline{7}$ )

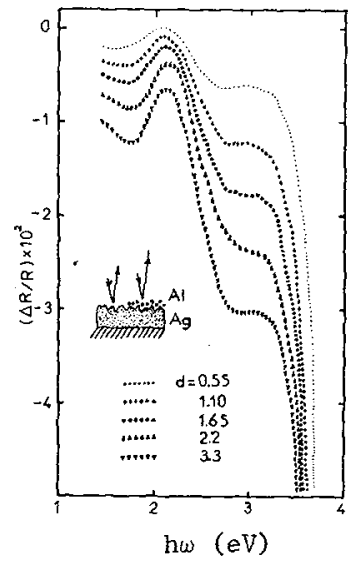

Fig. 2 - Differential reflectivity $\Delta R / R$ vshw for several Al superficial deposits on a Ag film 984 \& thick deposited on a substrate at $120 \mathrm{~K}$. 
the optical absorption at $\sim 1.8 \mathrm{eV}$ is due to localized resonances at the individual surface bumps and the $3 \mathrm{eV}$ absorption to the usual surface plasmon mode which manifests itself in an attenuated manner due to the large surface roughness.

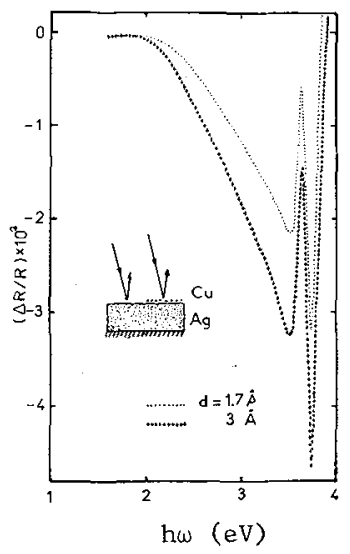

Fig. 3 - Differential reflectivity $\Delta R / R$ vshw for two superficial layers 1.7 and $3 \AA$ thick deposited and mesured at $140 \mathrm{~K}$ on a silver substrate ( $580 \AA$ thick) produced at room temperature.

only indicative of optical absorption in the Cu superficial layer but also of the field enhancement inside silver by surface plasmon excitation. In any case we can affirm, by comparing $\mathrm{fig} 1$ and 3 , that the field intensity $\left(\mathrm{E}^{2}\right)$ at $1.8 \mathrm{eV}$ for the quenched silver film is at least an order of magnitude greater than for the film deposited at room temperature. We must also bear in mind that we "see" the field at $\mathrm{Cu}$ and $\mathrm{AI}$ atom locations that may not be sites where the electromagnetic fields are highest.

Pockrand /7/ has carefully determined the SERS excitation spectra on Ag surfaces prepared by quenching silver in conditions identical to ours. He observed that the excitation spectra are independent of the investigated molecule (pyridine, $\mathrm{CO}, \mathrm{O}_{2}$, etc) and of the chosen vibration when the excitation profile is represented as a function of the Stokes frequency $\omega_{s}$ (and not of the laser frequency). An excitation spectrum taken from the Pockrand's work is represented in fig $1 \mathrm{~b}$. It is clear that the observed resonance in the SERS spectra is located at nearly the same frequency and has the same width as the optical absorption mesured by us. The excitation spectra represented as a function of the laser energy peak at different positions of our $\triangle R / R$ spectra depend on chosen lines, possibly indicating that the preponderant enhancement in SERS is in the stokes process. 


\section{REFERENCES}

/1/ LANDAU I., LIFCHIFTS, Electrodynamique des milieux continus Editions Mir Moscou 1969 p 333

/2/ POCKRAND I., BILLMANN J., OTTO A., J. Chem. Phys. in press

/3/ CREIGHTON J.A in Surface Enhanced Raman Scattering ed. by R.K. Chang and T.E. Furtak, Plenum Press, New York 1982 p 315

/4/ BERGMAN J.G, CHEMLA D.S., LIAO P.F., GLASS A.M., PINCZUK A., HART R.M., OLSON D.H. Opt. Lett. $\underline{6}(1981) 33$

/5/ WEITZ D.A. , GAROFF S., GRAMILA T.J Opt. Lett. $7(1982) 168$

/6/ LOPEZ-RIOS T., BORENSZTEIN Y., VUYE G. J. Physique Lett. 44 (1983)L99

/7/ POCKRAND I. Chem. Phys. Lett. 92(1982) 514 